
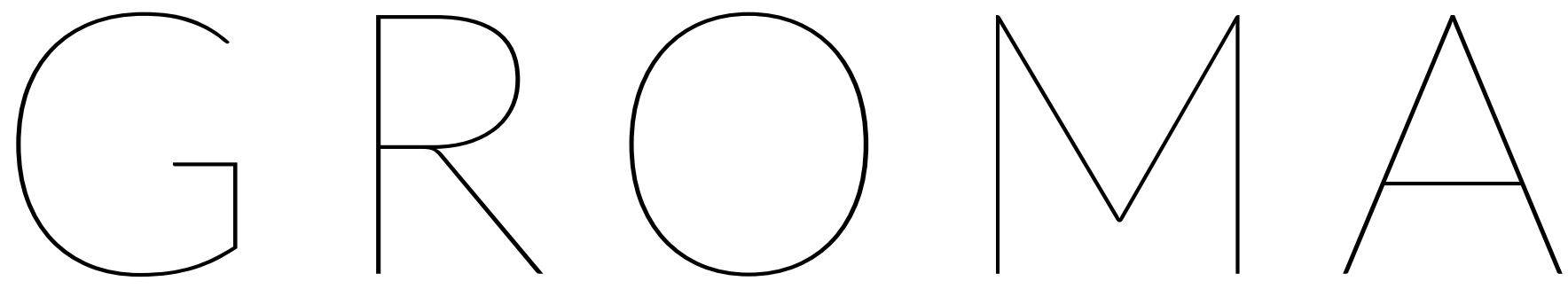

documenting archaeology | dept. of history and cultures, university of bologna

Open-Access E-Journal about methodology applied to archaeology http://groma.unibo.it

Maurizio Cattani,

Experimental Archaeology at the University of Bologna, widening and opening archaeological research

Volume 1-2016

pp. 1-11

DOI: 10.12977/groma129/03/2016

Publisher: BraDypUS [http://books.bradypus.net]

Publication date: 19/11/2015

ISSN: 2531-6672

License: CC BY-NC-ND 4.0 International

Section: Article 


\section{Experimental Archaeology at the University of Bolo- gna, widening and opening archaeological research}

The establishment of an Experimental Archaeology Laboratory at the University of Bologna has created the opportunity to offer students new training methods and to take on scientific research dedicated to the analysis and comprehension of ancient technologies. The Laboratory is based on the participation of several specialists, including archaeologists, technicians, ethno-archaeologists, and experts in archeometry, with the shared aim of investigating, documenting and understanding the past. Using limited financial resources, initial activities took place near the Bronze Age settlement of Solarolo, where the synergy among local institutions, land owners, academics and the general public created a basis on which to prepare activities and zones dedicated to different aspects of experimental archaeology.

\section{Experimental archaeology from a methodological and theoretical point of view}

In this paper, instead of discussing and stressing what Experimental Archaeology is, we want to propose some remarks on the role of this discipline inside academic education and more in general in archaeological research. The starting up of a Laboratory of Experimental Archaeology at the University of Bologna has been both the opportunity to open up new scientific research dedicated to the analysis and comprehension of ancient processes and at the same time it fills a gap in training students.

In the academic world, Experimental Archaeology has taken on a twofold meaning:

- as "applied archaeology" it equates to an important step in education, forcing students (but also seniors and teachers) to put their own knowledge into practice, turning them into real protagonists of the past';

- as a discipline, it is dedicated to "problem solving" in field research. Archaeologists try to understand and interpret contexts during field activities, mainly excavations, and they need to refer to all possible knowledge including their experience in experimental archaeology.

In both cases we assume that the discipline offers specific knowledge, unlikely to be obtained with traditional academic courses, which requires, besides a broadmindedness, a good mastery on production processes and materials. When considering the recent academic reforms, marked by the trend of reducing specializations, it seems unlikely that the Italian University will dedicate any resources in this

1 I owe Pino Pulitani for the interpretation and use of the term "applied archaeology". As a senior researcher in experimental archaeology, with his technical background he has stimulated many sectors in this research and he is still helping us to better understand how to put the discipline into practice. 
direction. For this reason the Laboratory of Experimental Archaeology is an opportunity to offer to the students an integration of methods and knowledge in their education, particularly useful or, according to some, absolutely necessary if the aim is to practice archaeology.

To avoid misunderstandings we would like to state what we intend with Experimental Archaeology, from the academic point of view and especially to remember what it is not. We avoid entering into the world of re-enacment and living history, greatly appreciated, but with different purposes, and instead we include the didactical and

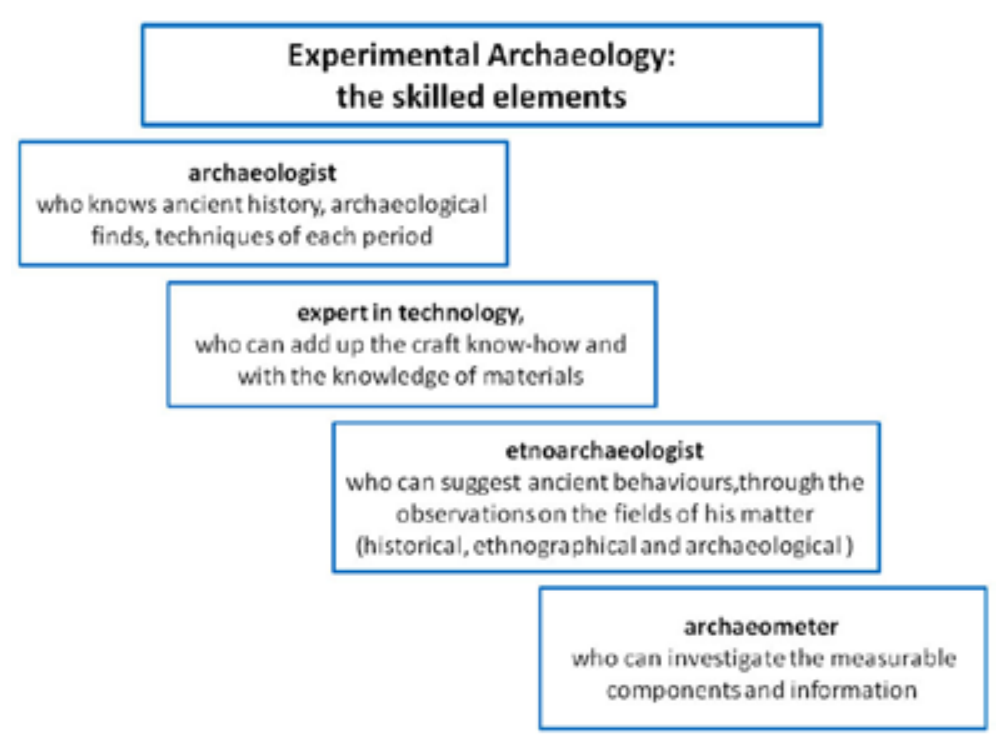

Fig. 1 - Elements and participants in the discipline of Experimental Archaeology efficacious involvement of the public, which can participate in some of the activities related to the applied experiments.

Experimental Archaeology is a way to investigate, document and know the past, with the contribution of several figures with their own mastery (Fig. 1). Among them, the archaeologist with his/her collection of historical sources, the ability to recognize finds, and general knowledge about what technology was in use in a specific period; the true expert in technology, with his/her know-how in several craft activities and a full knowledge of materials; the etnoarchaeologist, well versed in the observation and comparison of historical, ethnographical and archaeological situations, who can suggest ancient behaviors; and the archaeometer, with his/her ability to determine and quantify all the components and measurable data within a scientific background.

It is unlikely that a single scholar could provide all of these know-how, but it is not rare to find people in experimental archaeology that have enough experience and capability to better understand the details of ancient processes. Fundamentally they are able to shorten the reasoning process and they act as a means of confrontation among the above mentioned figures.

Experimental Archaeology is not a mere reproduction of artifacts. This sometimes is the result but not the main goal. It is more important to learn the full process of the analysis of objects, from the exploitation of raw materials to their multiple functions, including their use and frequent reuse.

This learning process is carried out in several phases from the collection of documents to technical analysis and at the end with the experiment. Each of these steps needs to follow rules, methods and protocols that certify the scientific process (documented, repeatable and confutable).

Certainly in the past any craft activity was based more on instinct, and not on a strict rule, based on years of attempts or on shareable know-how: our goal is to transform the same attempts of understanding these processes to a documented and written form. It is clear that the aim is not, for instance, to succeed in smelting metal and producing objects, simply making use of modern crafts, but to reproduce the technological processes known and used in the Bronze Age, using the raw materials that circulated at that time, defined by archaeometric analysis, the type of tools used in that region, documented and recognized by archaeologists, experimenting the technological process suggested by the expert of technology and following the suggestions taken by the observations of historical and ethnographic 
sources. In such a way we will understand better the whole technological and ideological processes implemented to create any object with its own function and peculiarity, including the symbolic one.

The investigation through experimental archaeology is therefore the only way to verify any hypothesis formulated on the archaeological evidence and understand steps and variables of ancient processes. The aim, consequently, is not to find a unique solution to the interpretive problems of the archaeological research, but to identify step by step the different and manifold methods.

\section{The work in progress at UniBO: approaches, methods and general considera- tions}

The Lab started in 2011 with a series of activities of research and training for seniors, members of a research team and academic staff. These activities were carried out in an informal way (in the sense of Mathieu 2002), requiring a period of configuring, refining and strengthening of methodology and organization. Using only very poor funds, the activities were organized to look for the collaboration of experts willing to stake their all on applying experimental archaeology with methods of recording and establishing protocols through a mutual discussion. The perspectives of valorization and diffusion of an archaeological site, like the Bronze age settlement of Solarolo (Fig. 2), were the key to creating synergy among local institutions, land owners, academic interests and public attraction. In this case, organizing open days with the visit to the excavation became the opportunity to merge all these components and start with the educational program of experimental archaeology for university students.

Several fields of research were, at

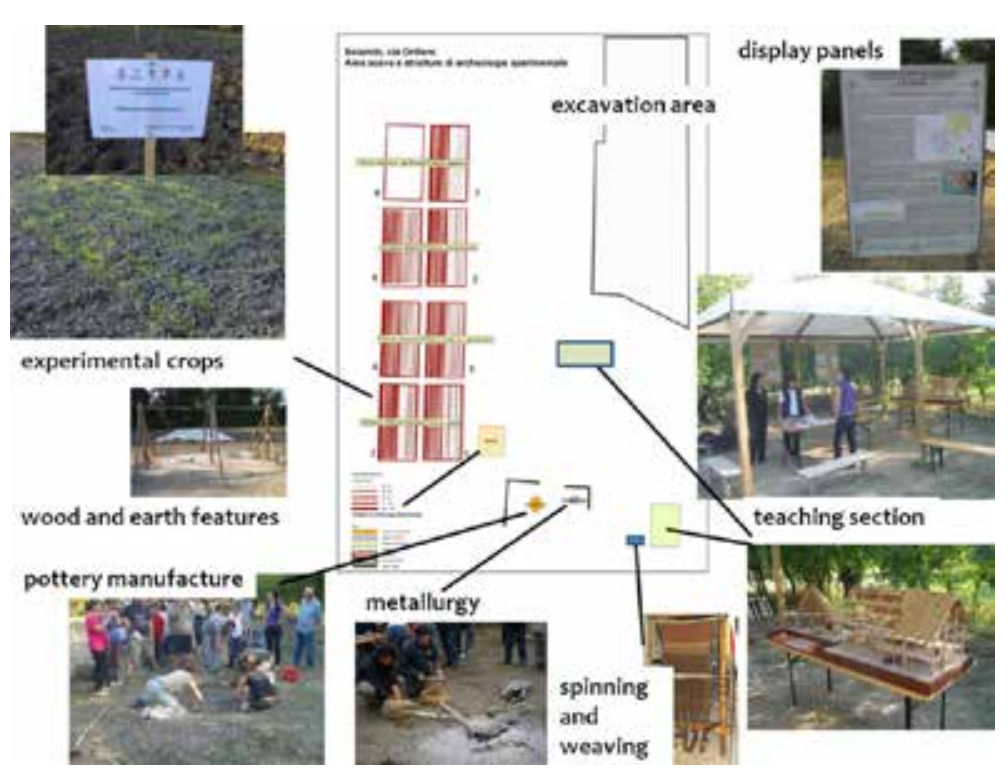

Fig. 2 - Solarolo (RA). Bronze Age settlement excavation area and Experimental Archaeology section that point, consistent with the archaeological excavation, and specific activities of experimental archaeology have been implemented to solve problems of identification and interpretation of features and finds:

- the pottery manufacturing during the Bronze Age (Fig. 3);

- the metallurgical production of bronze (Fig. 4, Fig. 5);

- earthen and wooden structures (Fig. 6);

- $\quad$ spinning and weaving (Fig. 7);

- experimental crops (Fig. 8);

- cooking system with a particular attention to cereals products (Fig. 9).

Another stage of the Lab was organized in a second center of research, in Sardinia, where the department is involved in research dedicated to the valorization of nuraghe Tanca Manna at Nuoro, 

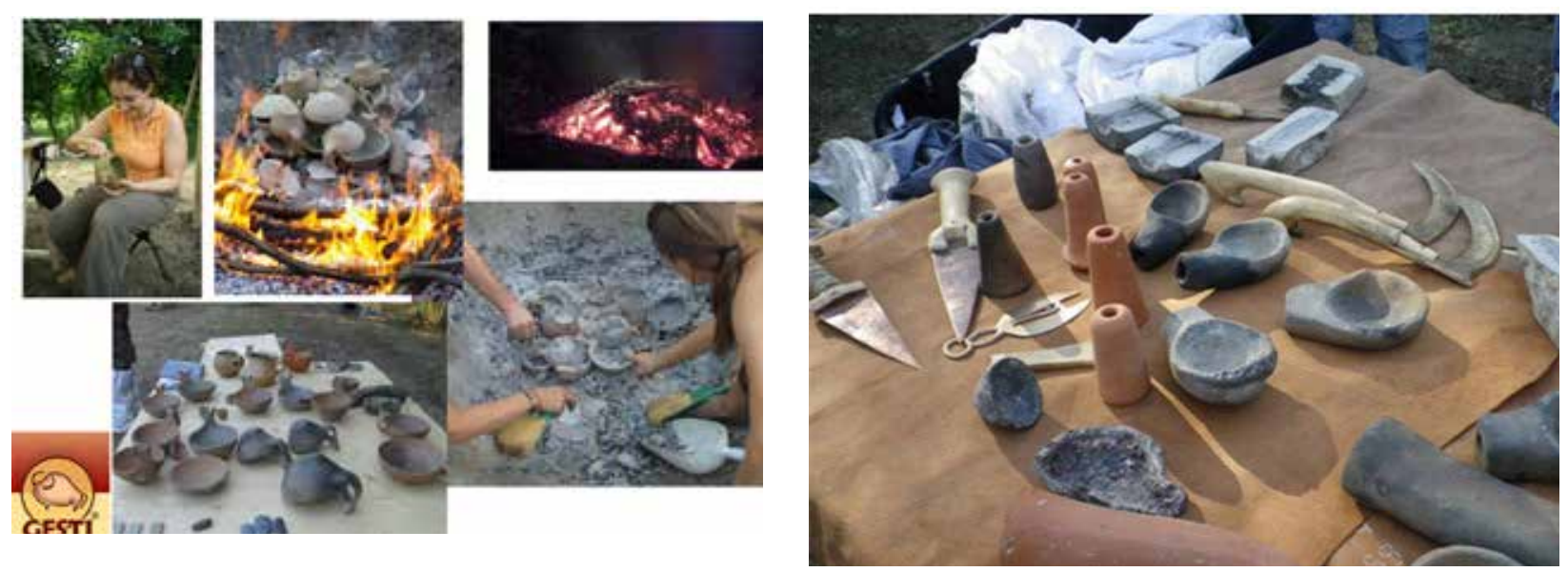

Fig. 3 - Solarolo (RA). Experimenting with pottery manufacturing

Fig. 4 - Solarolo (RA). The metallurgical production of bronze
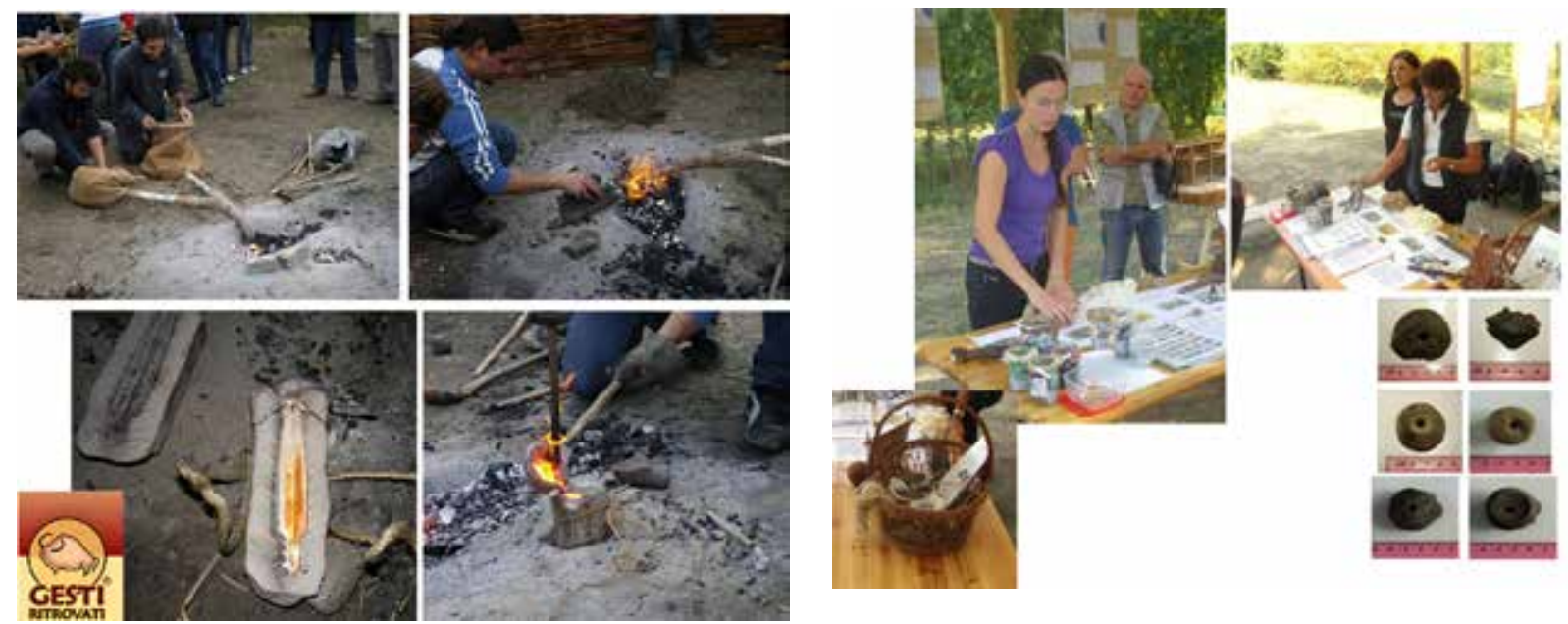

Fig. 5 - Solarolo (RA). Tools and features for smelting bronze

Fig. 6 - Solarolo (RA). Experimental Archaeology of earthen and wooden structures
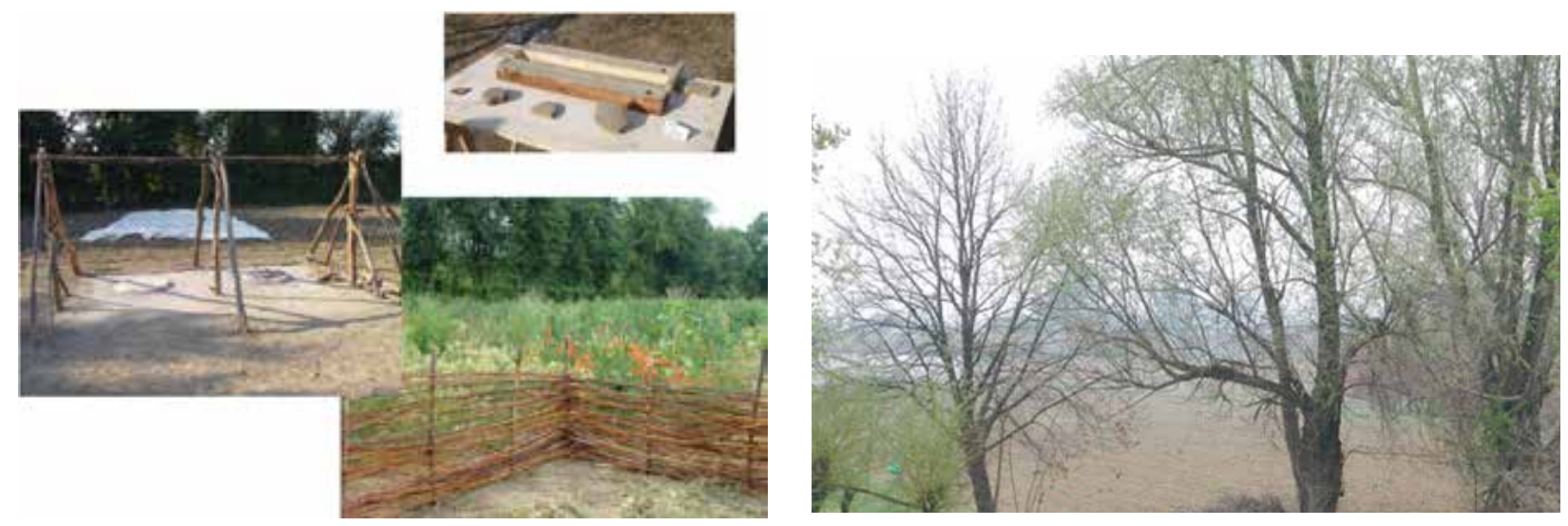

Fig. 7 - Solarolo (RA). Reconstructing spinning and weaving of animal and vegetal fibers

Fig. 8 - Solarolo (RA). Experimental crops of wheat, barley and flax

through forms of diffusion and participation of the local people (Fig. 10).

Regarding the methodology, we try to find efficacious solutions to make the best use of learning with external experts supported by protocols of documentation and data processing, suitable for students and scholars with no experience and skill. In particular, two main lines of action were established: broadening each topic and recording with forms and media (photo and video).

The first corresponds to the individual activities previewed by the academic rules for each laboratory or didactic activities and it is mainly based on data entry of archaeological finds, useful for under- 


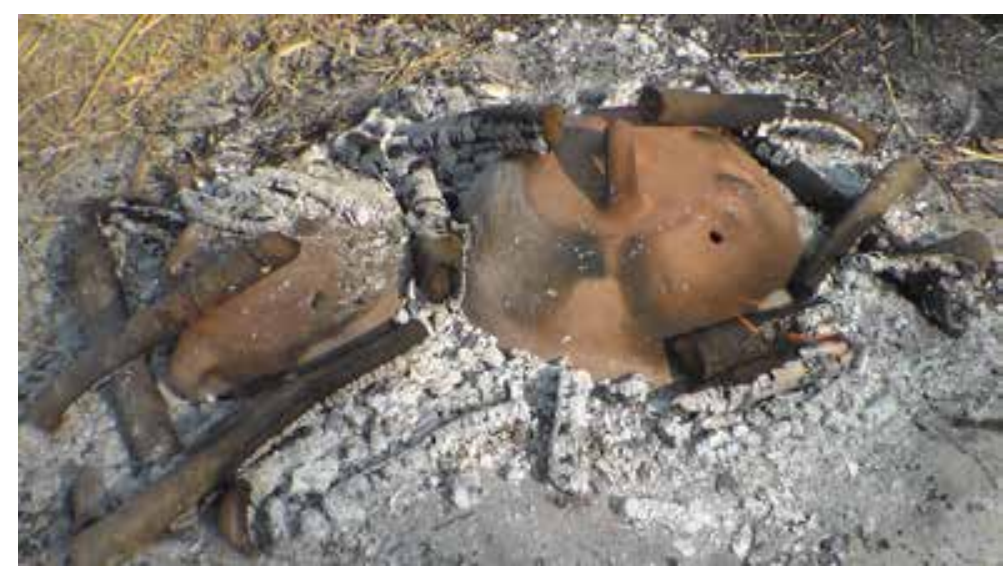

Fig. 9 - Solarolo (RA). Experimenting with cooking systems of bread and similar products

standing productive processes and their visibility in the archaeological record. The forms are part of a general database concerning the Bronze Age in Italy (sites, ceramic finds, metal finds, lithics, bibliography) in use for several years by the research group at UniBO.

The second line is dedicated more to the experimental activities in the field and requires for each participant to enter several observations carried out both directly during the experimentation and later combining more and more in depth knowledge. The forms (fig. 11) contain general notes recorded from the presentation of the teacher, observations of the process, and quantitative and qualitative data. From the contribution of all the participants at the end we can obtain a synthesis of the whole process, pointing out problematic aspects, failures, and also positive results of what was expected for each experiment.

Obviously the full process as any manual of experimental archaeology should require (Ferguson 2010) remains, in most cases conceptual and hard to create completely. In daily practice, the activities at the laboratory are more often single steps of the operational chain with direct methods, using materials and procedures not completely corresponding to those used in the past. An example of this shortening of the processes is the production of moulds for smelting bronze.

The correspondence of type of material between what is documented by finds and what has been collected for the experiment may have different levels of accuracy, from a general one (any stone) to the more specific and precise (the very identical kind of stone based on quarry provenance), passing through several intermediate steps (similar stone, coherence with outcrops in a region). Another factor of simplification in experimental processes concerns the use of modern tools which perform some of the steps in a faster way, in this case postponing the verification of parameters and variables of that particular step.

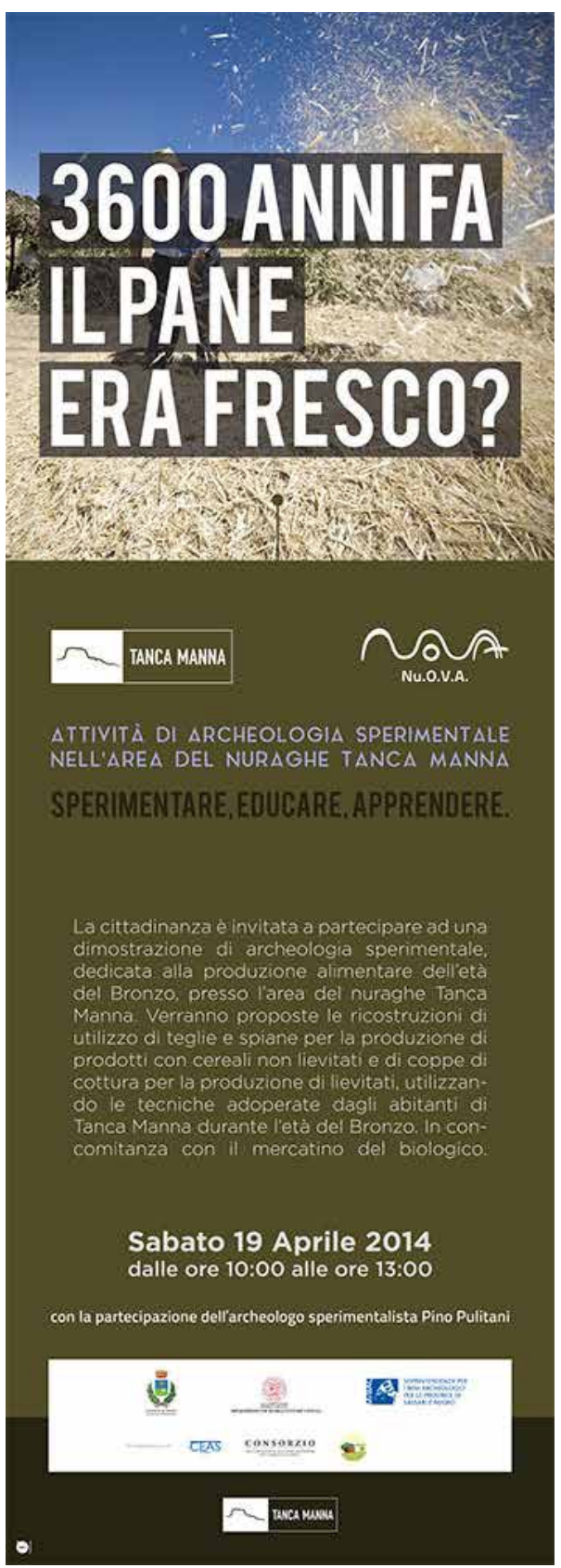

Fig. 10 - Nuoro. Open day with the participation of the public in experimental activities of cooking bread 


\section{The enforceability of methods: the definition of protocols}

The main aim of experimental archaeology is to create reasoning about ancient processes supported by protocols, according to scientific methods (Galilean) or more empiric methods. Naturally they both have produced results successfully when technicians have fully shared their knowledge with researchers and when the latter have stimulated the former about the formulation of problems. Archaeologists start from the field record and especially pay more attention to what technicians have observed. This feedback process is fully synergetic when other observers, even students, participate in the whole process. At this point an open and shared knowledge based on a semantic web could really improve the final results, making it evident that the Experimental Archaeologist has to be recognized not as a single figure, but rather a collective team.

The contribution of several figures allows us to build a protocol, useful for recording any step and necessary for being repeated in the later experiments. The forms drawn up by the students, the remarks of the teacher and the reasoning of the technician turn into a protocol with formulas, tools, and time of processing.

The result of several stages has produced nevertheless not a single protocol but alternative versions to be verified in the future. Protocols are not in this case a final solution, but rather a temporary registration of single experimentation, even if the aim is to reduce possible variations of the process.

\section{Final remarks}

Many of the directions taken on in the lab remain at their initial phase. What should follow is a long series of experimentations, organized in many sessions that will require repeating the operations or verifying during each one new parameters and other changes. During these experimentations we observe the many transformations from what we thought at the beginning, following also unexpected directions of the research. Some of these experiments can be considered short in terms of time, dedicated to specific problem solving, while others are scheduled for several years. An example is the project of experimental crops, in its third year of verification (Carra, Cattani, Debandi 2012). The main aim of the project is to take on all the problems of agriculture in the Bronze age, but it is mainly directed to facing the demographic problem, passing through all the parameters that could have affected the crop: soil suitability, weeds, and parasitic and climatic conditions.

Other projects are instead dedicated to solving specific and minor problems: for instance, the use of clay moulds for bronze smelting, starting from very few archaeological finds of this material and following the hypothesis that this scarce number is due mainly to the preservation process of clay objects, possibly unbaked.

Apart from several applied experiments, one of the main results of the laboratory is the involvement of students and scholars that at the end of the stage can acquire:

- a more detailed knowledge on the operational chain, more in depth with respect to what they can learn from books;

- the awareness of parameters and variables applied in the experimentation;

- a research method for classifying finds and contexts.

Some of the students have chosen to continue their interest in experimental archaeology extending their research with a thesis dissertation or similar experience applied in other centers of research in 
experimental archaeology. As in many other places and research centers, experimental archaeology is of increasing interest and involvement at several levels -academic, public and educational- which confirms the validity of this approach to archaeological research.

\section{Bibliographical note}

AA.VV. 1986. Cerchi di fuoco. Imitazioni di vita preistorica attraverso l'archeologia sperimentale. Assessorato alla Cultura del Comune di Verona.

1990. Interpretazione funzionale dei "fondi di capanna" di età preistorica, Atti del Seminario di Archeologia sperimentale (Milano, Civico Museo Archeologico 29-30.04.1989). Istituto Italiano per l'Archeologia sperimentale - Soprintendenza Archeologica della Lombardia. Genova.

1999. Experimental Archaeology. Convegno Internazionale di Archeologia sperimentale, Centro di Archeologia Sperimentale Torino in collaborazione con Civico Museo di Chiomonte. Torino 9/12 - 12 - 1999. Riassunti. Torino.

2002. Experimentelle Archaeologie. Bilanz 2001. Oldenburg: Aisensee Verlag.

Alhaique, Francesca and Cristina Lemorini. 1996. 'Butchering with stone tools: an experimental approach to use wear analysis and taphonomic studies of the archaeological material from Grotta Breuil', in Reduction processes ("chaînes opératoires") for the European Mousterian, Quaternaria Nova VI edited by Amilcare Bietti and Stefano Grimaldi, 393-412.

Anderson, Patricia C., Sylvie Beyries, Marcel Otte and Hugues Plisson, eds. 1993. Traces et fonctions : les gestes retrouvés, Actes du colloque international de Liège (8-10 décembre 1990). Liège.

Aubry, Thierry, Bruce Bradley, Miguel Almeida, Bertrand Walter, Maria João Neves, Jacques Pelegrin, Michel Lenoir and Marc Tiffagom. 2008. 'Solutrean laurel leaf production at Maitreaux: an experimental approach guided by techno-economic analysis', World Archaeology 40 (1): 48-66.

Balfet, Hèléne., ed. 1991. Observer l'action technique - des châines opératoires, pour quoi faire? Paris.

Benini A., V.T. Braggion, G. Chelidonio and G. Pasquali. 1988. 'From environment to prehistory: a proposal for a methodology of study and didactics', in Environment and school iniziative project. Italian report edited by M. Mayer. Frascati.

Bietti Sestieri, Anna Maria and Giuseppe Pulitani. 1992. 'Esperimento di riproduzione della ceramica di impasto', in La necropoli laziale di Osteria dell'Osa edited by Anna Maria Bietti Sestieri. Roma, 439447.

Binggeli, Markus, Adriano Boschetti and Felix Müller. 1997. 'Una dimostrazione di archeologia sperimentale: la fusione di oggetti in bronzo', in Le Terramare. La più antica civiltà Padana edited by Maria Bernabò Brea, Andrea Cardarelli and Mauro Cremaschi, 567-569. Milano.

Blockley, Marion. 2000. 'The social context for archaeological reconstruction in England, Germany and Scandinavia'. In Archaeologia Polona, 38: 43-68.

Bondioli, Luca, Giovanni Leonardi, Sara Tiziana Levi, Mario Micheli, Stefano Pracchia, Alessandro Vanzetti and Massimo Vidale. 1988. 'Archeologie di oggetti e archeologie di processi: stati della questione', in Preistoria Alpina 24: 203-215.

Broglio, Alberto, Giorgio Chelidonio and Laura Longo. 1990. 'Preliminar observation by techno experimental analysis on a blade and shouldered points lithic assemblage from Paina cave site (VicenzaItaly)'. In Traces et fonctions : les gestes retrouvés, Actes du colloque international de Liège (8-10 décembre 1990). Eraul n. 50. Vol 1 edited by Patricia C. Anderson, Sylvie Beyries, Marcel Otte, and Hugues Plisson, 31-40. Liège. 
Calegari, Giulio and Ian Lokosek. 1990. 'Simulazione di crollo e degrado di una capanna'. In Interpretazione funzionale dei "fondi di capanna" di età preistorica, Atti del Seminario di Archeologia sperimentale (Milano, Civico Museo Archeologico 29-30.04.1989), 17-18. Genova.

Calegari, Giulio, Laura Simone and Santo Tiné. 1990. 'Ricostruzione sperimentale di una capanna del Neolitico antico'. In Interpretazione funzionale dei "fondi di capanna” di età preistorica, Atti del Seminario di Archeologia sperimentale (Milano, Civico Museo Archeologico 29-30.04.1989), 9-16. Genova

Cappelli, R. 1998. Fidene. Una casa dell'età del Ferro. Roma.

Carra Marialetizia, Maurizio Cattani and Florencia Debandi. 2012. 'Coltivazioni sperimentali per una valutazione della produttività agricola dell'Età del Bronzo nell'area padana'. In Ipotesi di Preistoria 5 (1): $79-100$.

Chelidonio, Giorgio. 1982. 'Costruzione ed analisi sperimentale di una lampada in pietra. Analisi sperimentale della costruzione di una lampada in pietra tipo Lascaux - La Mouthe'. In Preistoria Alpina 18: 257- 262 .

1988. 'Experiments on boring-drilling technology: wear changes in tools shapes and micro-wear'. In Industries lithiques - tracéologie et technologie, vol. 1, C.N.R.S., B.A.R. International Series n. 411 edited by Sylvie Beyries, 295-308. Oxford: Archaeopress.

1988a. 'Archéologie expérimentale à Verone: 1983-1987. Expériences dans le domaine éducatif'. In L'archéologie et son image. VII Rencontres Internationales d'Archéologie et Histoire d'Antibes, Actes du Colloque 29-31 octobre 1987, 113-116. Antibes.

1991a. 'Learning the past, educating the future: Experimental archaeology as a main support to a method of environmental education through the sense of time and technobehavioural evolution'. In Experimentelle Archäologie. Bilanz 1991, 91-100. Oldenburg: Isensee Verlag.

1991b. 'Experimental archaeology as a main support toward an "environmental" method of learning: experineces in schools' didactics in Verona (1975-1987)'. In Archéologie expérimentale-Tome 1. Le Feu. Actes du Colloque International Expérimentation en archéologie: bilan et perspectives, Archeodrome de Beaune, 6-9 aprile 1988, 87-92. Paris: Edition Errance.

1992. Apprendimento, ambiente, origini. Firenze: La Nuova Italia Editrice.

1995. 'Memorie litiche: sperimentazione e analisi progettuale', in Le scienze della terra e l'archeometria edited by Claudio D'amico and Franco Finotti. Bologna: Pàtron, 69-72.

1997. 'Strumenti fossili: la sperimentazione archeologica come metodo per restituire la dinamica uomo-ambiente'. In La Scuola di Archeologia Subacquea di Peschiera del Garda edited by F. Giardina, 26-28. Peschiera del Garda.

2002. 'Flaking off the line of time: school experience in north-eastern Italy and method of using experimental stone knapping in teaching main steps in human adaptation evolution'. In Experimentelle Archaeologie. Bilanz 2001, 81-92. Oldenburg: Isensee Verlag.

2002. 'Quando le pietre focaie non erano "acciarini”. Tracce e appunti fra Paolo Orsi e Stefano De Stefani'. In Stefano De Stefani pioniere della ricerca preistorica veronese, Atti del Convegno di Fumane (VR) 26 maggio 2001. "Annuario Storico della Valpolicella", 119-124. Fumane.

Chelidonio, Giorgio and Elisabetta Mottes. 1995. 'Dai megaliti alle statue stele. Verifiche sperimentali ed osservazioni preliminari sugli aspetti tecnici di produzione dei monumenti di Arco'. in Le statue stele di Arco by Annaluisa Pedrotti, 90-106. Trento : Tipolitografia Artigianelli.

Chelidonio, Giorgio. and C. Zurbuchen-Malfer 2001. 'Archeologia sperimentale e pedagogia: un convegno europeo al Museo di Neanderthal', in Padusa-Notiziario CPSSAE XI (3): 13.

Coles, John. 1981. Archeologia sperimentale, Longanesi. Milano. 
Comis, Laura. 2010. 'Experimental Archaeology: methodology and new perspectives in Archaeological Open Air Museums'. In euroREA. Journal for (Re) construction and Experiment in Archaeology 7: 9-12.

Cunningham, Penny, Julia Heeb and Roeland Paardekooper, eds. 2008. Experiencing Archaeology by Experiment. Oxford: Oxbow.

De Beaune, Sophie A., 2000. Pour une archéologie du geste, Paris.

Dominiguez-Rodrigo, Manuel. 2008. 'Conceptual premises in experimental design and their bearing on the use of analogy: an example from experiments on cut marks'. In World Archaeology 40 (1): 67-82.

Dumas C., B. Roussel and P.J. Texier, eds. 2009. Langage de Pierre. La restitution du geste en archéologie préhistorique. Colloque Européen. Les Baux de Provence.

Evershed, Richard P. 2008. 'Experimental approaches to the interpretation of absorbed organic residues in archaeological ceramics'. In World Archaeology 40 (1): 26-47.

Workgroup del Centro di Archeologia sperimentale di Torino, ed. 2001. Experimental archeology or Experiments for archaeology? Atti del Convegno UISPP. Liège.

Formigli, Edilberto and Nele Hackländer. 1995. 'Le ricostruzioni sperimentali'. In I grandi bronzi antichi. Le fonderie e le tecniche di lavorazione dall'età arcaica al Rinascimento, Atti dei Seminari di studi ed esperimenti. Murlo 24-30 luglio 1993 e 1-7 luglio 1995 edited by E. Formigli, 299-334. Siena.

Francovich, Riccardo and Andrea Zifferero, eds.1997, Musei e parchi archeologici; IX ciclo di lezioni; Certosa di Pontignano (SI) - 1997. Firenze: All'insegna del Giglio.

Gaj, Giorgio and Orietta Maestro. 1999. 'Analisi tecnologica e riproduzioni sperimentali'. In In riva al Fiume Eridano. Una necropoli dell'età del Bronzo finale a Morano sul Po (Cat. mostra - Sopr. Arch. Piemonte; Mus. Civ. Casale Monferrato) edited by Marika Venturino Gambari, 91-96. Alessandria.

Giannichedda, Enrico. 2006. Uomini e cose. Appunti di archeologia. Bari: Edipuglia.

'Produzione e consumo. Archeologia, archeologia sperimentale, etnoarcheologia'. In Produzione e consumo dei manufatti edited by Enrico Giannichedda, 11-20. Bordighera.

1999. 'Prospettive di ricerca interdisciplinare nell'ambito archeologico sperimentale'. In Experimental archaeology, Convegno internazionale di archeologia sperimentale. Torino 9-12 dicembre 1999, 17-20. Torino.

Giannichedda Enrico and Tiziano Mannoni. 2003. 'Archeologia sperimentale e archeologia della prouzione'. In Archeologie sperimentali. Metodologie ed esperienze fra verifica, riproduzione, comunicazione e simulazione. Atti del convegno, Comano Terme - Fiavè Trento (Italy), 13-15 settembre 2001 edited by Paolo Bellintani and Luisa Moser, 33-39. Trento.

Gibbon G., 1989. Explanation in Archaeology. Oxford: Blackwell.

Guidi, Alessandro, Paolo Bellintani, Giorgio Chelidonio and Laura Longo. 2003. 'Archeologia sperimentale nell'archeologia italiana'. In Atti del conv. Archeologie sperimentali-Metodologie ed esperienze fra verifica, riproduzione, comunicazione e simulazione, Comano Terme - Fiavè 2001, 77-95. Trento.

Hurcombe, Linda. 2008. 'Organics from Inorganics: using experimental archaeology as a research tool for studying perishable material culture'. In World Archaeology 40 (1): 83-115.

Hurcombe, Linda. 2004. 'Experimental Archaeology', In Archaeology: the Key Concepts edited by Colin Renfrew and Paul Bahn, 110-115. London: Routledge.

Ingersoll D. and W. Macdonald 1977. 'Introduction'. In Experimental Archaeology edited by D. Ingersoll, J.E. Yellen and W. Macdonald, xi-xvii. New York: Columbia University Press.

Jeffra, Caroline. 2008. 'Hair and potters: an experimental look at temper'. In World Archaeology 40 (1): 151-161. 
Kelterborn, Peter. 1987. 'Principles of experimental research in archaeology'. In Bulletin of Experimental Archaeology 8: 11-12.

Lemorini, Cristina. 1999. 'Hide treatment in a Middle Palaeolithic site: use-wear analysis and experimental reconstruction of the chaînes opératoire'. In Urgeschichtliche Materialhefte 14: 22-33.

Lemorini, Cristina. 2000. Reconnaître des tactiques d'exploitation du milieu au Paléolithique Moyen. BAR International Series, 858. Oxford: Archaeopress.

Leroi-Gourhan, André. 1993-1994. Evoluzione e tecniche, voll. 1-2, Milano.

Longo, Laura. 2003. 'Archeologia sperimentale, esperimenti in archeologia, divulgazione. Osservazioni su significato e ruolo dell'Archeologia sperimentale'. In Rivista Scienze Preistoriche LIII: 549-568.

Longo, Laura., and Giorgio Chelidonio. 2002. 'Le "selci strane": un caso fra etnoarcheologia e implicazioni socio-economiche'. In Stefano De Stefani pioniere della ricerca preistorica veronese, Atti del Convegno di Fumane (VR) 26 maggio 2001. "Annuario Storico della Valpolicella” edited by Luciano Salzani and P. Brugnoli, 25-146. Verona.

Malina J., 1983. 'Archaeology and experiment'. In Norwegian Archaeological Review 16 (2): 69- 85.

Mannoni, Tiziano and Enrico Giannichedda. 1996. Archeologia della produzione. Torino: Loescher.

Mathieu, James R. 2002. 'Introduction'. In Experimental Archaeology: Replicating Past Objects, Behaviours and Processes. BAR International Series 1035, edited by J. R. Mathieu, 1-12. Oxford: Archaeopress.

Mathieu, James R. 2002: 'Introduction'. In Experimental Archaeology, Replicating Past Objects, Behaviours and Processes. BAR International Series 1035 edited by J.R. Mathieu. Oxford: Archaeopress, $1-12$.

Mathieu, James R. 2005. 'For the reader's sake: publishing experimental archaeology'. In EuroREA 2: 110.

Merlo, Riccardo. 1990. 'Ricostruzioni per la divulgazione e la didattica'. In Lo scavo archeologico: dalla diagnosi all'edizione, II ciclo lezioni Certosa di Pontignano (SI) - 1988 edited by Riccardo Francovich and Daniele Manacorda, 547-578. Firenze: All'insegna del Giglio.

Miller, Heather M. L. 2008. Archeological approaches to technology. London.

Millson, D. C. E. 2010. Experimentation and interpretation: the use of experimental archaeology in the study of the past. Oxford: Oxbow.

Mithen, Steven, Emma Jenkins, Khalil Jamjoum, Sameeh Nuimat, Stephen Nortcliff and Bill Finlayson. 2008. 'Experimental crop growing in Jordan to develop methodology for the identii cation of ancient crop irrigation'. In World Archaeology 40 (1): 7-25.

Molloy, Barry. 2008. 'Martial arts and materiality: a combat archaeology perspective on Aegean swords of the fifteenth and fourteenth centuries BC'. In World Archaeology 40 (1): 116-134.

Outram, Alan K. 2005. 'Publishing archaeological experiments: a quick guide for the uninitiated'. In EuroREA 2: 107-9.

Outram, Alan K. 2008. 'Introduction to experimental archaeology'. In World Archaeology 40 (1): 1-6.

Pleterski, Andrej. 2008. Kuhinjska kultura v zgodnjem srednjem veku. Slovenian with comprehensive German summary. Ljubljana.

Priuli, Aurelio. 1990. Rivivere la preistoria, Museo didattico d'Arte e Vita Preistorica. Capo Di Ponte.

Renfrew, Colin and Paul Bahn. 1995. s.v. 'Archeologia sperimentale'. In Archeologia-teoria - metodi pratica, 246, 274-276, 279 (scheda 2.1 and 178). Bologna.

Reynolds, Peter J. 1999. 'The nature of experiment in archaeology'. In Experiment and Design: Archaeological Studies in Honour of John Coles edited by Anthony. F. Harding, 148-162. Oxford: Oxbow. 
Richter P. B. 1991. 'Experimentelle Archäologie: Ziele, Methoden und Aussagemöglichkeiten'. In Experimentelle Archäologie, Bilanz 1991, Archäologische Mitteilungen aus Nordwestdeutschland, Beihet 6 edited by M. Fansa, 19-49. Oldenburg.

Saraydar, Stephen C. 2008. Replicating the past: the art and science of the archaeological experiment. Long Grove: Waveland Press.

Schmidt, Martin. 2005. 'Remarks to the publication of archaeological experiments'. In EuroREA 2: 112113.

Semenov, Sergě̃ Aristarkhovich. 1964. Prehistoric Technology. Bradfordon-Avon: Moonraker.

Seetah Krish. 2008. 'Modern analogy, cultural theory and experimental replication: a merging point at the cutting edge of archaeology'. In World Archaeology 40 (1): 135-150.

Schiffer, Michael Brian. 2013. 'Contributions of Experimental Archaeology'. In The Archaeology of Science- Studying the Creation of Useful Knowledge edited by Michael.B. Schiffer, 43-52. Springer International Publishing.

Shimada, Izumi. 2005. 'Experimental Archaeology'. In Handbook of Archaeological Methods, Vol. I edited by Herbert D.G. Maschner and Christopher Chippindale, 603-642. Lanham: AltaMira Press.

Vidale, Massimo. 1992. Produzione Artigianale Protostorica. Etnoarcheologia e Archeologia. Padova: Saltuarie del Laboratorio del Piovego.

. 2000. 'Sperimentale, archeologia'. In Dizionario di Archeologia. Temi, concetti e metodi edited by Riccardo Francovich and Daniele Manacorda, 280-282. Bari - Roma: Laterza.

Zifferero, Andrea. 2003. 'Archeologia sperimentale e parchi archeologici'. In Atti del conv. Archeologie sperimentali-Metodologie ed esperienze fra verifica, riproduzione, comunicazione e simulazione. Comano Terme - Fiavè 2001, 49-76. Fiavè. 